\section{Adverse reactions to intravenous anaesthetic induction agents}

Adverse reactions to intravenous anaesthetic agents have been increasingly reported in recent years. ${ }^{1}$ Many of these reports have concerned the relatively new agents Althesin (alphadolone and alphaxalone in polyoxyethylated castor oil; Glaxo) and propanidid (Epontol; propanidid in polyoxyethylated castor oil; Bayer), which seem to produce adverse reactions more often than established agents such as methohexitone and thiopentone. Although these agents, with the probable exception of propanidid, are widely used to induce: anaesthesia, a reliable estimate of the incidence of adverse reactions has not been established. ${ }^{1}+$ We therefore conducted a retrospective study of adverse reactions to intravenous induction agents in a large department of anaesthetics.

\section{Methods}

The survey was confined to the agents Althesin, methohexitone (Brietal sodium; Lilly), propanidid, and thiopentone (Intraval Sodium; May and Baker) in use in the hospitals of the South Glamorgan Area Health Authority from January 1973 to December 1976.

Number of administrations - The number of administrations of each agent was estimated from the records of supplies to operating theatres held by hospital pharmacies. All the agents were stocked and in use at the beginning of the survey period. We assumed, on the basis of our experience, that the agents were always prepared for administration in standard quantities: Althesin $5 \mathrm{ml}$, methohexitone $100 \mathrm{mg}$, propanidid $1000 \mathrm{mg}$, and thiopentone $500 \mathrm{mg}$. We made no allowances for waste, or for the use of larger or repeated doses (which would have decreased the estimate), or of smaller doses (which would have increased the estimate). As a rough check on this

TABLE I-Estimated number of administrations of anaesthetic agents

\begin{tabular}{|c|c|c|}
\hline \multicolumn{2}{|l|}{$\begin{array}{c}\text { Agent } \\
\text { (standard dose) }\end{array}$} & $\begin{array}{c}\text { Estimated } \\
\text { administrations } \\
\left({ }^{\prime}{ }_{0}\right)\end{array}$ \\
\hline $\begin{array}{l}\text { Althesin }(5 \mathrm{ml}) \\
\text { Methohexitone }(100 \mathrm{mg}) \\
\text { Propanidid }(1000 \mathrm{mg}) \\
\text { Thiopentone }(500 \mathrm{mg})\end{array}$ & $\begin{array}{l}\cdots \\
\cdots \\
\cdots\end{array}$ & $\begin{aligned} & 18587(17 \cdot 1) \\
& 2530(2 \cdot 3) \\
& 1110(1 \cdot 0) \\
& 86481(79 \cdot 6)\end{aligned}$ \\
\hline \multicolumn{2}{|c|}{ Total } & $108708(100 \cdot 0)$ \\
\hline
\end{tabular}

estimate the rough number of general anaesthetics given in the period was derived from Hospital Activity Analysis records.

Collection of reports-All anaesthetists who had worked in the area during the study period were either interviewed or sent an explanatory letter and questionnaire. They were asked for details of adverse reactions associated with the intravenous induction of anaesthesia. For the purpose of this study we defined an adverse reaction as a reaction that required immediate additional treatment - for example, a rapid intravenous infusion of fluid. Mild reactions, such as an erythematous rash, were therefore excluded. In addition we sought relevant details of patients' medical histories and previous anaesthetic and drug exposure, and checked by reference to the hospital notes whenever possible. Duplicate reports were carefully identified. If an obvious alternative explanation for the reaction was evident-for example, bronchospasm after endotracheal intubation in an asthmatic patient-we disregarded the report.

\section{Results}

Number of administrations-The number of administrations of the four intravenous agents estimated from pharmacy records was 108700 (table I). This was similar to the estimate of the number of general anaesthetics given in the same period (108 500), derived from Hospital Activity Analysis records. Thiopentone was used for $80 \%$ of inductions and Althesin for $17 \%$. Both methohexitone and propanidid were used in only $3 \%$ of cases.

Number of adverse reactions-One hundred and two anaesthetists were interviewed or sent postal questionnaires. Twenty-two postal questionnaires were unanswered. Thirty-four reactions, none fatal, were reported, 26 associated with Althesin and eight with thiopentone. No reactions were associated with methohexitone or propanidid. About three-quarters of the reactions occurred in women. Eight reports were disregarded; in six cases (four associated with Althesin and two with thiopentone) a reasonable alternative explanation was evident. Two reports were disregarded because they contained insufficient information. In six well-documented reports (four associated with Althesin and two with thiopentone), the patient could not be identified and further reference to the hospital notes was not possible. In these instances the anaesthetist was contacted and questioned to confirm and clarify details of the reaction. The reports were divided into three groups: those showing features of histamine release ("histaminoid" reactions); those concerning neuromuscular changes; and a miscellaneous group.

Reactions associated with Althesin-Ten histaminoid reactions were reported. In three cases cardiac arrest was diagnosed clinically and external cardiac massage begun. Three patients who had previously received Althesin uneventfully developed reactions (case numbers $1,8,10$; see table II) to the second dose. In only one patient was a history of drug sensitivity obtained. Four reactions (cases $5,6,7,8$ ) occurred after less than $0.5 \mathrm{ml}$ Althesin had been used to flush the intravenous cannula ; subsequent induction of anaesthesia with thiopentone was uncomplicated. Only one patient received other drugs intravenously with Althesin; repeated administration of these drugs (atropine and suxamethonium) with thiopentone was uneventful. Four patients with no history of convulsions or epilepsy developed generalised convulsions controlled by thiopentone. Three patients developed muscular

TABLE II-Principal features of adverse reactions associated with Althesin (estimated administrations 19000 )

\begin{tabular}{|c|c|c|c|c|c|c|}
\hline No & $\begin{array}{c}\text { Age } \\
\text { (years) }\end{array}$ & Sex & Reaction & Operation & Medical details & Other details \\
\hline $\begin{array}{l}1 \\
2 \\
3\end{array}$ & $\begin{array}{r}60 \\
5 \\
70\end{array}$ & $\begin{array}{l}M \\
M \\
\mathrm{~F}\end{array}$ & $\begin{array}{l}\text { Histaminoid: } \\
\text { Erythema; bronchospasm; cardiac arrest } \\
\text { Bronchospasm; cyanosis; cardiac arrest }\end{array}$ & $\begin{array}{l}\text { Cystoscopy } \\
\text { Orthopaedic }\end{array}$ & & Althesin uneventfully 2 months earlier \\
\hline & 70 & & Bronchospasm; cyanosis; cardiac arrest & Electric convulsion therapy & Hypertension, digitalised & $\begin{array}{l}\text { Also given atropine, suxamethonium (see } \\
\text { text) }\end{array}$ \\
\hline $\begin{array}{l}4 \\
5\end{array}$ & 24 & $\begin{array}{l}\mathrm{M} \\
\mathrm{F}\end{array}$ & $\begin{array}{l}\text { Erythema; hypotension; tachycardia } \\
\text { Erythema; hypotension; tachycardia }\end{array}$ & $\begin{array}{l}\text { Orthopaedic } \\
\text { Dilatation and curettage } \\
\text { (D \& C ) }\end{array}$ & & $\begin{array}{l}\text { Young adult } \\
\text { Althesin dose } 0.5 \mathrm{ml}\end{array}$ \\
\hline 6 & 27 & $M$ & $\begin{array}{l}\text { Erythema; tachycardia; dyspnoea; facial } \\
\text { oedema }\end{array}$ & Cataract & $\begin{array}{l}\text { Schizophrenia; on } \\
\text { phenothiazines }\end{array}$ & Althesin dose $0.5 \mathrm{ml}$ \\
\hline 7 & 51 & $\mathrm{~F}$ & Erythema; tachycardia & $D \& C$ & Mild asthma & $\begin{array}{l}\text { Althesin dose } 0.5 \mathrm{ml} \text {. Allergic to } \\
\text { tetracycline }\end{array}$ \\
\hline 8 & 17 & F & $\begin{array}{l}\text { Erythema; bronchospasm; dyspnoea; } \\
\text { abdominal pain }\end{array}$ & Excision of ganglion & Migraine & $\begin{array}{l}\text { Althesin dose } 0.5 \mathrm{ml} \text {. Althesin unevent- } \\
\text { fully } 5 \text { months earlier }\end{array}$ \\
\hline $\begin{array}{r}9 \\
10\end{array}$ & $\begin{array}{r}51 \\
8\end{array}$ & $\stackrel{\mathrm{F}}{\mathrm{F}}$ & $\begin{array}{l}\text { Erythema; hypotension; tachycardia } \\
\text { Coughing; erythema; hypotension; } \\
\text { tachycardia }\end{array}$ & $\begin{array}{l}\text { Excision of naevus } \\
\text { Marrow biopsy }\end{array}$ & $\begin{array}{l}\text { Leukaemia; } \\
\text { immunotherapy }\end{array}$ & Althesin uneventfully 2 weeks earlier \\
\hline 11 & 28 & $\mathrm{~F}$ & $\begin{array}{l}\text { Neuromuscular: } \\
\text { Generalised convulsion }\end{array}$ & Cystoscopy & Depression; on diazepam & $\begin{array}{l}\text { Premed: atropine, morphine. No } \\
\text { diazepam preoperatively }\end{array}$ \\
\hline $\begin{array}{l}12 \\
13 \\
14 \\
15\end{array}$ & $\begin{array}{r}25 \\
27 \\
? \\
49\end{array}$ & $\begin{array}{l}\mathrm{F} \\
\mathrm{F} \\
\mathrm{F}\end{array}$ & $\begin{array}{l}\text { Generalised convulsion } \\
\text { Generalised convulsion } \\
\text { Generalised convulsion } \\
\text { Muscle rigidity; airway obstruction; } \\
\text { cyanosis }\end{array}$ & $\begin{array}{l}\text { Cervical cautery } \\
\text { D \& C } \\
\text { D \& C } \\
\text { D \& C }\end{array}$ & & $\begin{array}{l}\text { Premed: hyoscine, papaveretum } \\
\text { Premed: hyoscine, papaveretum } \\
\text { Premed: hyoscine, papaveretum } \\
\text { Premed: hyoscine, papaveretum }\end{array}$ \\
\hline 16 & 39 & $\mathrm{~F}$ & $\begin{array}{l}\text { Muscle rigidity; airway obstruction; } \\
\text { cyanosis }\end{array}$ & $\mathrm{D} \& \mathrm{C}$ & & Premed: hyoscine, papaveretum \\
\hline 17 & 50 & $\mathbf{M}$ & $\begin{array}{l}\text { Muscle rigidity; apnoea; cyanosis } \\
\text { Miscellaneous: }\end{array}$ & Osteotomy & & Premed: Nil \\
\hline $\begin{array}{l}18 \\
19\end{array}$ & $\begin{array}{l}34 \\
33\end{array}$ & $\underset{F}{F}$ & $\begin{array}{l}\text { Apnoea for } 10 \mathrm{~min} \\
\text { Apnoea for } 60 \mathrm{~min}\end{array}$ & $\begin{array}{l}\mathrm{D} \& \mathrm{C} \\
\text { Evacuation of uterus }\end{array}$ & Depression & $\begin{array}{l}\text { Premed: hyoscine, papaveretum } \\
\text { Premed: morphine } 10 \mathrm{mg} \text {. Atropine }\end{array}$ \\
\hline 20 & ? & $\mathrm{F}$ & Bronchospasm & $\mathrm{D} \& \mathrm{C}$ & & Premed: ? \\
\hline
\end{tabular}


TABLE III-Principal features of adverse reactions associated with thiopentone (estimated administrations 86000 )

\begin{tabular}{|c|c|c|c|c|c|c|}
\hline No & $\begin{array}{c}\text { Age } \\
\text { (years) }\end{array}$ & Sex & Reaction & Operation & Medical details & Other details \\
\hline 1 & 16 & $\mathrm{~F}$ & $\begin{array}{l}\text { Histaminoid: } \\
\text { Bronchospasm; cyanosis; cardiac arrest; } \\
\text { facial oedema }\end{array}$ & Appendicectomy & & $\begin{array}{l}\text { Also given atropine, suxamethonium. } \\
\text { Allergic to adhesive plaster }\end{array}$ \\
\hline 2 & 28 & $\mathrm{~F}$ & $\begin{array}{l}\text { Bronchospasm; hypotension; cardiac } \\
\text { arrest }\end{array}$ & Tubal ligation & & $\begin{array}{l}\text { Also given suxamethonium, pancuronium. } \\
\text { Allergic to penicillin }\end{array}$ \\
\hline 3 & 21 & $\mathrm{~F}$ & $\begin{array}{l}\text { Bullous skin lesion; hypotension } \\
\text { Miscellaneous: }\end{array}$ & Dilatation and curettage & & \\
\hline $\begin{array}{l}4 \\
5 \\
6\end{array}$ & $\begin{array}{c}67 \\
78 \\
?\end{array}$ & $\begin{array}{l}\mathrm{M} \\
\mathrm{M} \\
\mathrm{F}\end{array}$ & $\begin{array}{l}\text { Cyanosis; hypotension; cardiac arrest } \\
\text { Cyanosis; hypotension; cardiac arrest } \\
\text { Rigidity of jaw muscles; laryngospasm; } \\
\text { cyanosis }\end{array}$ & $\begin{array}{l}\text { Cystoscopy } \\
\text { Ureterotomy } \\
\text { Dilatation and curettage }\end{array}$ & $\begin{array}{l}\text { Ischaemic heart disease } \\
\text { Ischaemic heart disease } \\
\text { Obese, heavy smoker }\end{array}$ & Also given pancuronium \\
\hline
\end{tabular}

rigidity with apnoea or airway obstruction managed by muscular paralysis and endotracheal intubation. Two patients developed apnoea of ten and 30 minutes' duration.

Reactions associated with thiopentone-Three histaminoid reactions were reported which led to cardiac arrest in two patients (table III). Both of these patients had a history of allergy, one to penicillin and the other to adhesive strapping, and each received other drugs-atropine and suxamethonium (case 1), and suxamethonium and pancuronium (case 2). In another two patients, cardiac arrest preceded by hypotension was reported; both were elderly, aged 67 and 78 respectively, with ischaemic heart disease and impaired renal function. These reactions were believed to have resulted from a relative overdose of thiopentone.

Incidence of reactions - The overall incidence of adverse reactions associated with Althesin was one in 930 ( $95^{\circ} \%$ confidence limits: one in 650 to one in $1650)$, and with thiopentone one in 14000 (95\% confidence limits: one in 6600 to one in 39300 ). The incidence of histaminoid reactions to Althesin was one in 1900 and thiopentone one in 29000 . The incidence of other adverse reactions after Althesin was one in 1900 and one in 29000 for thiopentone.

\section{Discussion}

We found that the incidence of adverse reactions to Althesin was fifteen times greater than that to thiopentone. Previous estimates of the incidence of adverse reactions to Althesin have varied. Clarke et al correlated a series of spontaneous reported adverse reactions (including those submitted to the Committee on Safety of Medicines) with the national sales of Althesin, and estimated the overall incidence to be one in $11000 .^{2}$ Watt ${ }^{3}$ and Fisher ${ }^{4}$ both reported four histaminoid reactions in 3500 administrations (one in 900).

A predominance of female patients as in this series was also found in the series reported by Clarke et al." The selective use of Althesin in short gynaecological procedures and preponderance of women patients requiring anaesthesia in our series (about $60 \%$ ) may account for this bias. The incidence of reactions would have been higher if any of the 22 anaesthetists who did not reply to questionnaires had reported adverse reactions.

The reactions associated with Althesin reported in this study were similar to those previously reported, except for the two cases of apnoea. Short periods of apnoea may be produced by a relative overdose of intravenous anaesthetic agent; in neither case did we consider this a satisfactory explanation. The four reports of convulsions after Althesin in fit patients raises the question of its safety in patients with a predisposition to convulsions. Enhancement of epileptiform electroencephalographic changes after Althesin have been observed in patients with pre-existing intracranial disease and previously detected electroencephalographic changes." The incidence of neuromuscular reactions to Althesin is influenced by the rate of injection and choice of premedication. ${ }^{6}$ - Although Althesin was not injected rapidly in the three cases of severe muscle rigidity, the use of hyoscine for premedication in two cases may have contributed to the severity of the reactions.

Serious adverse reactions to thiopentone have been considered uncommon, only 30 cases having been reported. ${ }^{1}$ The reactions associated with thiopentone reported to us were notable only for their rarity. Possibly the true incidence of adverse reactions is greater. Retrospective collection of reports of adverse reactions to long-established agents is likely to be incomplete. The collection of reactions associated with a new agent such as Althesin, however, is likely to be more reliable.

Two factors may explain the substantial discrepancy between our estimates of the incidence of adverse reactions to Althesin and those made by Clarke et al. ${ }^{2}$ Firstly, our definition of an adverse reaction probably encouraged the reporting of reactions other than histaminoid reactions. Secondly, the collection of reports by questionnaire and interview is certain to be more productive than spontaneous reporting. Only nine of the 26 reactions collected by us were published or reported to the Committee on Safety of Medicines. The deficiency of spontaneous reporting as a method of assessing adverse reactions is well recognised, and has become a matter of public concern. ${ }^{8}$ Proposals to overcome this by a system of monitored or controlled release have recently been discussed. ${ }^{9}$ New anaesthetic agents could be subject to monitored release with relative ease since their administration is performed and closely supervised by anaesthetists. Most important reactions to a new induction agent, for example, could be shown by monitoring 10000-20000 administrations.

The relative safety of Althesin as an induction agent must again be questioned. ${ }^{3}{ }^{410}$ Although Althesin has the advantages over thiopentone of causing little postanaesthetic sedation and little irritation when given extravenously or intra-arterially, we believe the high incidence of adverse reactions (approximately one in 1000 administrations) increases the risks of anaesthesia to a generally unacceptable level.

We should like to thank Professor M D Vickers, Dr J N Lunn, and Mr M I J Hogg for their advice; and Mr B Evans, principle pharmacist, University Hospital of Wales, and Dr P Grundy, Department of Social Medicine, Welsh National School of Medicine, for their help.

${ }^{1}$ British fournal of Anaesthesia, 1976, 48, 57.

2 Clarke, R S J, et al, British fournal of Anaesthesia, 1975, 47, 575

3 Watt, J M, British Medical fournal, 1975, 3, 205.

${ }^{4}$ Fisher, M McD, Anaesthesia and Intensive Care, 1975, 3, 180

${ }^{5}$ Comelli, L F, Pignatelli, M G, and Varrassi, G, Anesthesiology, Proceedings of VI World Congress of Anesthesiology. Amsterdam, Excerpta Medica, 1977.

6 Samuel, I O, and Dundee, J W, British fournal of Anaesthesia, 1973, 45, 1215.

' Clarke, R S J, et al, British Fournal of Anaesthesia, 1972, 44, 845.

${ }^{8}$ Lancet, 1976, 2, 1312.

${ }_{9}$ British Medical fournal, 1977, 1, 861.

${ }^{10}$ Avery, A F, and Evans, A, British fournal of Anaesthesia, 1973, 45, 301.

(Accepted 26 fuly 1977)

Department of Anaesthetics, University Hospital of Wales, Heath Park, Cardiff CF4 4XW

J M EVANS, FFARCS, senior registrar

J A M KEOGH, FFARCSI, registrar

\section{Generalised allergic reaction to monocomponent insulin}

Generalised allergic reactions to insulin were recognised soon after its introduction into medicine. ${ }^{1}$ Both a delayed-type hypersensitivity and an immediate-type hypersensitivity to insulin have been described. ${ }^{2} 3$ These reactions are, however, extremely rare and they have not been reported with the monocomponent insulins. We describe here a patient who developed a generalised allergic reaction to a monocomponent insulin.

\section{Case report}

A 23-year-old female diabetic developed a local weal to soluble insulin when it was given for a short period in 1965. The insulin was stopped and she 